\title{
Aspirin inhibits cholangiocarcinoma cell proliferation via cell cycle arrest in vitro and in vivo
}

\author{
TINGTING SHI ${ }^{1}$, JIAN GONG ${ }^{2}$, KOJI FUJITA ${ }^{1}$, NORIKO NISHIYAMA ${ }^{1}$, HISAKAZU IWAMA ${ }^{3}$, \\ SHI LIU ${ }^{2}$, MAI NAKAHARA ${ }^{1}$, HIROHITO YONEYAMA ${ }^{1}$, ASAHIRO MORISHITA ${ }^{1}$, TAKAKO NONURA ${ }^{1}$, \\ HIDEKI KOBARA ${ }^{1}$, KEIICHI OKANO ${ }^{4}$, YASUYUKI SUZUKI ${ }^{4}$ and TSUTOMU MASAKI ${ }^{1}$ \\ ${ }^{1}$ Department of Gastroenterology and Neurology, Faculty of Medicine, Kagawa University, Kida, \\ Kagawa 761-0793, Japan; ${ }^{2}$ Department of Gastroenterology, The First Affiliated Hospital of Dalian Medical University, \\ Dalian, Liaoning 116011, P.R. China; ${ }^{3}$ Life Science Research Center, Kagawa University; \\ ${ }^{4}$ Department of Digestive Surgery, Faculty of Medicine, Kagawa University, Kida, Kagawa 761-0793, Japan
}

Received June 24, 2020; Accepted October 23, 2020

DOI: $10.3892 /$ ijo.2020.5165

\begin{abstract}
Cholangiocarcinoma is the most common biliary duct malignancy and the second most common primary liver cancer, accounting for $10-20 \%$ of hepatic malignancies. With high mortality and poor prognosis, the 5-year survival rate of cholangiocarcinoma is only $10 \%$. A previous study demonstrated a significant association between aspirin use and a decreased risk of cholangiocarcinoma. However, the effect of aspirin on cholangiocarcinoma remains unknown. Therefore, the aim of the present study was to investigate the effects of aspirin on cholangiocarcinoma in vitro and in vivo. Three cholangiocarcinoma cell lines were used to analyze the effect of aspirin on cell proliferation, cell cycle progression, apoptosis, and the regulation of microRNAs. MicroRNAs are known to regulate the development and progression of various types of cancer. An HuCCT-1 xenograft model was used for the in vivo study. It was determined that aspirin inhibited the proliferation of human cholangiocarcinoma cells (except TKKK cells). Aspirin induced cell cycle arrest in the $\mathrm{G}_{0} / \mathrm{G}_{1}$ phase and regulated cell-cycle related proteins in cholangiocarcinoma cells
\end{abstract}

Correspondence to: $\mathrm{Dr}$ Tsutomu Masaki, Department of Gastroenterology and Neurology, Faculty of Medicine, Kagawa University, 1750-1 Ikenobe, Miki, Kida, Kagawa 761-0793, Japan

E-mail: tmasaki@med.kagawa-u.ac.jp

Abbreviations: CCA, cholangiocarcinoma; NSAID, non-steroidal anti-inflammatory drug; FCM, flow cytometer; AMPK, AMP-activated protein kinase; miRNA, microRNA; NF- $\kappa$ B, nuclear factor $\kappa$-light-chain-enhancer of activated B cells; JNK, c-Jun-N-terminal kinase; GSK-3, glycogen synthase kinase-3; mTOR, mammalian target of rapamycin; STAT3, signal transducers and activators of transcription 3; p-Bcl-2, phosphorylated B-cell lymphoma-2; ELISA, enzyme-linked immunosorbent assay; Cdk, cyclin-dependent kinase

Key words: aspirin, cell cycle, cholangiocarcinoma, in vivo, microRNAs
(HuCCT-1 cells) but did not induce apoptosis. The expression of miR-340-5p was significantly upregulated after treatment, and overexpression of miR-340-5p inhibited the proliferation of HuCCT-1 cells and decreased the levels of cyclin D1. TKKK cells had low miR-340-5p expression, which may explain why aspirin had no effect on their proliferation. In vivo, aspirin reduced the growth of xenografted tumors. In conclusion, the present study indicated that aspirin partially inhibited cholangiocarcinoma cell proliferation and tumor growth by inducing $\mathrm{G}_{0} / \mathrm{G}_{1}$ phase cell cycle arrest, potentially through the miR-340-5p/cyclin D1 axis.

\section{Introduction}

Cholangiocarcinoma (CCA) is the most common biliary duct malignancy and the second most common primary liver cancer, accounting for $10-20 \%$ of all primary hepatic malignancies (1).CCA arises from bile duct epithelial cells, and there are three subtypes based on anatomic location: Intrahepatic (iCCA), perihilar (pCCA), and distal (dCCA). The etiology of CCA includes lithiasis (2), primary sclerosing cholangitis (3), parasitic infection (4), congenital abnormalities (5), chronic liver disease (6), cirrhosis (6), metabolic abnormalities (7), and lifestyle (7). The incidence of iCCA appears to be increasing (8); the rates of CCA in North America, Japan, and Australia have been rising over the past two decades (9). Although surgery is the preferred treatment, the 5-year postoperative survival rate is markedly low. Chemotherapy can be used for inoperable cases; however, the highly desmoplastic nature, rich tumor microenvironment, and profound genetic heterogeneity all contribute to iCCA therapeutic resistance (9).

The nonsteroidal drug aspirin is an anti-inflammatory and anticoagulation agent used to prevent and reduce the risk of cardiovascular events. According to some clinical analyses, long-term use is also associated with a reduction in cancer risk, including colon (10), breast (11), and hepatocellular carcinoma (12). Aspirin use also has a significant inverse association with the development of all three CCA subtypes and an approximately 3 -fold reduction in CCA risk (13). Numerous anticancer mechanisms for aspirin have been 
identified, such as inhibition of cyclooxygenase (14), activating key molecular targets in the AMPK, mTOR, STAT3, and $\mathrm{NF}-\kappa \mathrm{B}$ pathways (15), decreasing the levels of reactive oxygen species and glucose consumption (16), inducing autophagy via JNK/p-Bcl2/Beclin-1, AMPK/mTOR, and GSK-3 signaling (17), inducing apoptosis and mitochondrial dysfunction by increasing oxidative stress (18), and changing the tumor microenvironment by affecting platelets $(19,20)$. However, the effect of aspirin on CCA remains unknown. Elucidation of the mechanism of aspirin in CCA could contribute to the development of new therapeutic agents in the future.

The purpose of the present study was to determine the antitumor effects of aspirin in CCA and identify the key molecular targets and microRNAs (miRNAs) associated with this effect.

\section{Materials and methods}

Chemicals. Aspirin was obtained from Wako Pure Chemical Industries, Ltd. The prepared solution was diluted in cell culture medium as per the requirement of cells and fresh pH 7.2 to 7.5 , within the range suitable for cell growth was used.

Cell lines and cell culture. Human CCA cell lines (HuCCT-1, $\mathrm{RBE}$, and TKKK) were obtained from the Japanese Research Resources Bank. HuCCT-1 and RBE cells were grown in RPMI-1640 media (Gibco-Invitrogen; Thermo Fisher Scientific, Inc.) supplemented with $10 \%$ fetal bovine serum (FBS) (product no. 557-30355; FUJIFILM Wako Pure Chemical Industries, Ltd.) and penicillin/streptomycin (100 mg/l; Invitrogen; Thermo Fisher Scientific, Inc.). TKKK cells were maintained in DMEM (Gibco-Invitrogen; Thermo Fisher Scientific, Inc.) supplemented with 10\% FBS and penicillin/streptomycin. All cell lines were grown in a humidified incubator at $5 \% \mathrm{CO}_{2}$ and $37^{\circ} \mathrm{C}$.

Cell viability assay. Cell viability assays were performed using the Cell Counting Kit-8 (Dojindo Molecular Technologies, Inc.) according to the manufacturer's instructions. Briefly, cells $(5,000$ cells in $100 \mu \mathrm{l} /$ well) were seeded into 96 -well plates and allowed to adhere, followed by treatment with $0,2.5,5$, or $10 \mathrm{mmol} / \mathrm{l}$ aspirin for $48 \mathrm{~h}$. The medium was replaced with $100 \mu \mathrm{l}$ of fresh medium containing $10 \%$ of CCK- 8 reagent, and cells were incubated at $37^{\circ} \mathrm{C}$ for $3 \mathrm{~h}$. The absorbance was measured at $450 \mathrm{~nm}$ using a multi-grating microplate reader SH-9000Lab (CORONA Electric Co., Ltd.). Experiments were carried out three times. Compared with RBE, HuCCT-1 cells were more sensitive to aspirin treatment in the cell viability assay. Moreover, considering the xenograft model, HuCCT-1 cells can be easily transplanted. Thus, HuCCT-1 cells were selected for further study in vitro and in vivo.

Flow cytometric analysis of the cell cycle. Flow cytometric analyses were performed using the Cycle Phase Determination kit (Cayman Chemical Company). HuCCT-1 and TKKK cells (1.0x $10^{6}$ cells $/ 100-\mathrm{mm}$ dish) were treated with $2.5 \mathrm{mmol} / 1$ aspirin or without for 24 to $48 \mathrm{~h}$. Cells were trypsinized and resuspended in phosphate-buffered saline (PBS) at a density of $1 \times 10^{6}$ cells $/ \mathrm{ml}$. Approximately $1 \times 10^{6}$ cells were stained in $100 \mu \mathrm{l}$ of PBS with $10 \mu \mathrm{l}$ RNase A $(250 \mu \mathrm{g} / \mathrm{ml})$ and $10 \mu \mathrm{l}$ propidium iodide (PI) stain $(100 \mu \mathrm{g} / \mathrm{ml})$ and incubated at room temperature in the dark for $30 \mathrm{~min}$. Flow cytometry (FCM) was performed to compare the proportion of aspirin-treated and control cells in each phase of the cell cycle. FCM was performed using a Cytomics FC 500 flow cytometer (Beckman Coulter, Inc.) with an argon laser (488 nm), and the percentages of cells were analyzed using the Kaluza software version v2.1 (Beckman Coulter, Inc.). The experiments were repeated thrice.

Apoptosis analysis. Aspirin-mediated apoptosis was analyzed using FCM and Annexin V-FITC Early Apoptosis Detection kit (Cell Signaling Technology, Inc.). HuCCT-1 cells (1.0x $10^{6}$ cells $/ 100-\mathrm{mm}$ dish) were treated with $2.5 \mathrm{mmol} / 1$ aspirin or without for $48 \mathrm{~h}$. Apoptotic and necrotic cells were analyzed by double staining with FITC-conjugated Annexin V and PI per the manufacturer's instructions. FCM was conducted using a Cytomics FC 500 flow cytometer with an argon laser $(488 \mathrm{~nm})$ to compare the proportion of apoptotic cells in the aspirin-treated and control groups, and data were analyzed using the Kaluza software version v2.1. The experiments were repeated thrice.

Apoptosis analysis by ELISA. ELISA was performed to analyze the levels of caspase-cleaved cytokeratin 18 (cCK18) using the M30 Apoptosense ELISA kit (cat. no. 10011; Peviva; Diapharma) according to the manufacturer's instructions. HuCCT-1 cells (5,000 cells/well) were seeded into 96-well plates and treated with $2.5 \mathrm{mmol} / \mathrm{l}$ aspirin for $48 \mathrm{~h}$. Subsequently, the cells were lysed in polyoxyethylene octyl phenyl ether (Pure Chemical Industries, Ltd.) and further analyzed according to the manufacturer's instructions. The experiments were repeated thrice.

Western blot analysis. HuCCT-1 and TKKK cells were seeded $\left(1.0 \times 10^{6}\right.$ cells $/ 100-\mathrm{mm}$ dish $)$ and treated with $2.5 \mathrm{mmol} / \mathrm{l}$ aspirin for 24 or $48 \mathrm{~h}$. The cells were lysed with PRO-PREP complete protease inhibitor mixture (iNtRON Biotechnology, Korea). Supernatants were collected, and the protein concentrations were measured using a NanoDrop 2000 spectrofluorometer (Thermo Fisher Scientific, Inc.). Protein aliquots $(10 \mu \mathrm{g})$ were resuspended in sample buffer and separated on $12 \%$ Tris-glycine gradient gels via sodium dodecyl sulfate-polyacrylamide gel electrophoresis. The resolved proteins were transferred to a nitrocellulose membrane and blocked with a blocking buffer containing $2 \%$ skimmed milk (GE Healthcare) in TBST with $0.1 \%$ Tween 20 (cat. no. T9142; Takara Bio, Inc.) for $30 \mathrm{~min}$ at room temperature. Subsequently, the membranes were incubated overnight at $4{ }^{\circ} \mathrm{C}$ with primary antibodies in 5\% serum (cat. no. 9048-46-8; FUJIFILM Wako Pure Chemical Industries, Ltd.) followed by incubation with horseradish peroxidase (HRP)-conjugated secondary antibodies in $2 \%$ skimmed milk. The following primary antibodies were used: Cyclin D1 (SP4) (1:2,000 dilution; cat. no. MA5-14512), retinoblastoma $(\mathrm{Rb})$ (1:1,000 dilution; cat. no. MA1-34070), and cyclin E (HE-12) (1:1,000 dilution; MS-870-P1) were obtained from Thermo Fisher Scientific, Inc.; phosphorylated Rb (pS780) (1:1,000 dilution; cat. no. 558554) was obtained from BD Biosciences; Cdk2 
(1: 5,000 dilution; cat. no. sc-163) was obtained from Santa Cruz Biotechnology, Inc.; and anti- $\beta$-actin (1:5,000 dilution; product no. A5441) was purchased from Sigma-Aldrich; Merck KGaA. The membranes were washed again with TBST and incubated with HRP-conjugated anti-mouse (dilution 1:2,000; product no. 7076) and anti-rabbit (dilution 1:2,000; product no. 7074) IgG secondary antibodies obtained from Cell Signaling Technology, Inc. for $1 \mathrm{~h}$ at room temperature. Finally, the signals were visualized using a typically enhanced chemiluminescent (ECL) kit (cat. no. 45-000-999; Cytiva), and blots were imaged using ImageQuant LAS 4010 (GE Healthcare).

miRNA microarray. Cells were treated with $2.5 \mathrm{mmol} / \mathrm{l}$ aspirin for $48 \mathrm{~h}$, and total RNA was extracted using the miRNeasy Mini kit (Qiagen $\mathrm{GmbH}$ ) according to the manufacturer's instructions. After confirming the purity and quantity of each sample using an Agilent 2100 Bioanalyzer and an RNA 6000 Nano kit (both from Agilent Technologies), respectively, the samples were labeled using a miRCURY Hy3 Power Labeling kit (Exiqon A/S) and hybridized to a human miRNA Oligo Chip (v.21; Toray Industries, Inc.). Chips were scanned using the 3D-Gene Scanner 3000 (Toray Industries, Inc.). The 3D-Gene extraction software version 1.2 (Toray Industries, Inc.) was used to calculate the raw signal intensity of the images. The raw data were analyzed using the GeneSpring GX 10.0 software (Agilent Technologies, Inc.) to assess the differences in miRNA expression between the aspirin-treated and control samples. Global normalization was performed on raw data obtained above the background level. Differentially expressed miRNAs were determined using Welch's t-test.

Reverse transcription-quantitative polymerase chain reaction (RT-qPCR) analysis of miRNAs. qPCR was used to validate the expression levels obtained from the miRNA assay. Total RNA was extracted as previously described above and diluted to $2.0 \mathrm{ng} / \mu 1$. TaqMan microRNA assays (Applied Biosystems; Thermo Fisher Scientific, Inc.) were adopted to determine the expression of miRNAs using U6 small nuclear RNA (RNU6B) as an internal control. miRNAs were reverse transcribed using the TaqMan microRNA Reverse Transcription kit (Applied Biosystems; Thermo Fisher Scientific, Inc.). Reverse transcription was performed in $20-\mu 1$ reaction volumes consisting of $5 \mu \mathrm{l}$ of RNA, $3 \mu \mathrm{l}$ of $5 \mathrm{X}$ RT primer, and $12 \mu \mathrm{l}$ of reverse transcription Master Mix. qPCR was performed in the MicroAmp Fast Optical 96-Well Reaction Plate (Applied Biosystems; Thermo Fisher Scientific, Inc.). Each well contained a $20-\mu 1$ reaction consisting of $2 \mu \mathrm{l}$ of cDNA, $1 \mu \mathrm{l}$ of 20X qPCR assay, $7 \mu \mathrm{l}$ of nuclease-free water, and $10 \mu \mathrm{l}$ of TaqMan Fast Advanced Master Mix (Applied Biosystems; Thermo Fisher Scientific, Inc.). PCR was performed using the ViiA7 real-time PCR system (Applied Biosystems; Thermo Fisher Scientific, Inc.) with the following reaction steps: Hold at $50^{\circ} \mathrm{C}$ for $2 \mathrm{~min}$, denaturation at $95^{\circ} \mathrm{C}$ for $20 \mathrm{sec}$ followed by 40 cycles of $1 \mathrm{sec}$ at $95^{\circ} \mathrm{C}$ and $20 \mathrm{sec}$ at $60^{\circ} \mathrm{C}$. The relative expression of miR-340-5p was calculated using the comparative $\mathrm{Cq}$ method according to the following formula: $2^{-\Delta \Delta \mathrm{Cq}}$ $(\Delta \mathrm{Cq}=$ miRCq-U6Cq, $\Delta \Delta \mathrm{Cq}=\Delta \mathrm{Cq}$-average control $\Delta \mathrm{Cq})(21)$. The primer sequences are as follows: miR-340-5p forward, 5'-GCGGTTATAAAGCAATGAGA-3' and reverse, 5'-GTG
CGTGTCGTGGAGTCG-3'; U6 forward, 5'-GCTTCGGCA GCACATATACTAAAAT-3' and reverse, 5'-CGCTTCACG AATTTGCGTGTCAT-3'.

Bioinformatics analysis used for prediction of the target genes of miR-340-5p and functional and network analyses. For bioinformatics analysis, miRDB database (www.mirdb.org) was used to predict the target genes of miR-340-5p and the Kyoto Encyclopedia of Genes and Genomes (KEGG) pathway analyses was used for upregulated miRNAs depending on the Database for Annotation, Visualization, and Integrated Discovery (DAVID database) (22). miRNA regulatory network used mirPath v.3 (http://snf-515788.vm.okeanos.grnet. gr) (23); miRGator v3.0 (http://mirgator.kobic.re.kr) (24) and miTarBase (http://mirtarbase.cuhk.edu.cn/php/index.php) (25) online software to reveal the expression of miR-340-5p in related cancer and normal tissue and the relationship with the underlying target gene. The cut-off criterion was set as $\mathrm{P}<0.05$.

Cell transfection. For transfection, $5 \times 10^{5} \mathrm{HuCCT}-1$ cells were seeded in 6-well plates with antibiotic-free medium 1 day before transfection to reach a confluence of $90 \%$ at the time of transfection. Cells were transfected with miR-340-5p mimic (50 nM) (sense, 5'-UUAUAAAGCAAUGAGACUGAUU-3' and antisense, 5'-UCAGUCUCAUUGCUUUAUAATT-3'), inhibitor (50 nM) (5'-AAUCAGUCUCAUUGCUUUAUA A-3'), or negative control miRNA $(50 \mathrm{nM})$ (mimic negative control 5'-UUGUACUACACAAAAGUACUG-3'; inhibitor negative control 5'-CAGUACUUUUGUGUAGUACAA-3') (Life Technologies; Thermo Fisher Scientific, Inc.) using Lipofectamine RNAiMAX Reagent (Invitrogen; Thermo Fisher Scientific, Inc.). The transfection complex was prepared according to the manufacturer's instructions and added to the cells, and the plates were incubated in a humidified atmosphere with $5 \% \mathrm{CO}_{2}$ at $37^{\circ} \mathrm{C}$. Cells cultured with transfection reagent as untransfected control. The medium was replaced $6 \mathrm{~h}$ post-transfection. Cell samples were collected at 0 or $48 \mathrm{~h}$ after transfection for further analysis.

Colony formation assay. Cells were trypsinized for $5 \mathrm{~min}$ and resuspended at a density of $1 \times 10^{3} / \mathrm{ml}$. Five hundred microliters were seeded into 6-well plates, and $1.5 \mathrm{ml}$ RPMI-1640 medium containing $10 \% \mathrm{FBS}$ was added to each well. The plates were incubated at $37^{\circ} \mathrm{C}$ at $5 \% \mathrm{CO}_{2}$, and the medium was changed every 3 days until conspicuous colonies were observed. Colonies were stained with $0.1 \%$ crystal violet for $5 \mathrm{~min}$ at room temperature and positive colony formation ( $>50$ cells/colony) was evaluated by counting the number of colonies.

Xenograft model analysis. The animal study was conducted in accordance with the guidelines set by the Committee on Experimental Animals of the Kagawa University. All experimental protocols were approved (approval no. 18674) by the Institutional Review Board of the Department of Laboratory Animal Science of Kagawa University (Kawaga, Japan). Thirty-five female athymic mice (BALB/c-nu/nu; 6 weeks old; 19-21 g) were purchased from Japan SLC (Shizuoka, Japan). The mice were maintained at $20-25^{\circ} \mathrm{C}$ with $30-60 \%$ humidity under a 12:12 h light/dark cycle, using a laminar airflow rack 
and had continuous free access to sterilized ( $\gamma$-irradiated) food (CL-2; CLEA Japan, Inc.) and autoclaved water. Mice were subcutaneously inoculated with $1.5 \times 10^{6}$ HuCCT- 1 cells in the right flank. When the xenografts were palpable with an approximate diameter of $3 \mathrm{~mm}$, we randomly assigned the animals to three groups of 10 animals each. These groups were treated with $60 \mathrm{mg} / \mathrm{kg}$ aspirin, $100 \mathrm{mg} / \mathrm{kg}$ aspirin, or vehicle (10\% ethanol in PBS) by intraperitoneal injection every day. The tumor volume $\left(\mathrm{mm}^{3}\right)$ was calculated as tumor length $(\mathrm{mm}) \times$ tumor width $(\mathrm{mm})^{2} / 2$. For humane endpoints, if difficulty in feeding and/or intake of water; apparent poor physical condition; a rapid and non-recoverable weight loss (over 20\% body weight); and/or a significant increase in tumor size was observed (tumor size more than $10 \%$ of body weight and/or tumor diameter more than $20 \mathrm{~mm}$ ), the experiments were discontinued. Animals were euthanized through $\mathrm{CO}_{2}$ euthanasia with $20 \%$ displacement of cage volume $/ \mathrm{min}$. Sacrifice was confirmed by observation of unconsciousness, absence of heartbeat and absence of breathing. All animals were sacrificed on day 28 of treatment. The experiments were performed from February 20, 2019 to March 28, 2019.

Immunohistochemistry. Immunohistochemistry was performed on tumor tissues obtained from the xenografted mice. We prepared $5-\mu \mathrm{m}$-thick sections from formalin-fixed (10\% formalin at room temperature for $24 \mathrm{~h}$ ), paraffin-embedded tissue blocks which were deparaffinized, rehydrated, and subjected to immunohistochemistry studies. Following a blocking step at room temperature for $30 \mathrm{~min}$ using a Vectastain Elite ABC kit (Vector Laboratories, Inc.), tissue sections were incubated with primary antibodies [Cyclin D1 (EP12); 1:200 dilution; cat. no. 241R-4, Sigma-Aldrich; Merck KGaA]. Sections were washed and incubated with anti-rabbit IgG Antibody (1:50 dilution; cat. no. BP-9100-50; Vector Laboratories) at room temperature for $1 \mathrm{~h}$ and then with a streptavidin-peroxidase solution. Color reactions involved the use of 3,3'-diaminobenzidine (DAB) with Mayer's hematoxylin counterstaining at room temperature for $10 \mathrm{sec}$. The specificity of immunostaining was evaluated using non-immune mouse IgG (1:50 dilution; cat. no. BP-9200-50; Vector Laboratories) at room temperature for $1 \mathrm{~h}$ as a negative control for the primary antibody. Sections were examined microscopically for specific staining, and nuclei with a brown color regardless of staining intensity were regarded as positive. Cyclin D1 positivity was calculated at a magnification of $\mathrm{x} 40$ by dividing the number of positive cells by the total number of cells counted in five random fields and expressed as a percentage. Images were captured using an Olympus BX51 microscope and Olympus DP72 camera (magnification, x40; Olympus Corporation).

Statistical analysis. GraphPad Prism software version 6.0 (GraphPad Software, Inc.) was used for all analyses. A two-tailed unpaired Student's t-test was used to determine statistical significance between different groups. Two-way analysis of variance (ANOVA) or mixed ANOVA was performed to test the comparisons and corrected by Tukey's post hoc test. One-way analysis of variance before the Tukey's post hoc test was performed to test the comparisons. A P-value of $<0.05$ was considered to indicate a statistically significant difference.

\section{Results}

Aspirin inhibits the proliferation of most human CCA cells. The anti-proliferative effects of aspirin on human CCA cells were determined using the HuCCT-1, RBE, and TKKK CCA cell lines. Cells were treated with $2.5,5$, or $10 \mathrm{mmol} / 1$ aspirin for $48 \mathrm{~h}$, and the anti-proliferative effect of aspirin was assessed using the cell viability assay. Untreated cells were used as controls. Aspirin inhibited cell proliferation in CCA cells in a dose and time-dependent manner, except in TKKK cells (Fig. 1).

Aspirin induces cell cycle arrest in the $G_{0} / G_{1}$ phase and

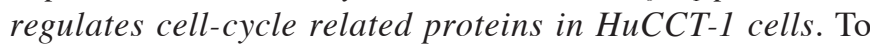
determine whether aspirin affected the cell cycle in CCA cells, HuCCT-1 cells were treated with aspirin and FCM was performed to examine cell cycle progression. Western blotting was also performed to evaluate the expression of cell-cycle related proteins. Cells were treated with $2.5 \mathrm{mmol} / \mathrm{l}$ aspirin for 24 or $48 \mathrm{~h}$, and untreated cells were used as the control. Following aspirin treatment, the population in the $G_{0} / G_{1}$ phase significantly increased, whereas cells in the $S$ phase decreased (Fig. 2A and B). Western blot results indicated that treatment with aspirin for $48 \mathrm{~h}$ significantly modulated cyclin D1, a key protein expressed in the early $G_{1}$ phase. Cyclin D1 is a key regulator of the cell cycle and is involved in the transition from the $G_{1}$ phase to the $S$ phase (26). The levels of phosphorylated $\mathrm{Rb}$ decreased with aspirin treatment, suggesting that the treated cells were in $\mathrm{G}_{1}$ arrest (Fig. 2C).

Aspirin does not induce cell apoptosis in HuCCT-1 cells. To determine whether aspirin induced apoptosis in HuCCT-1 cells, FCM was used to detect apoptotic cells after aspirin treatment. The different quadrants represent living cells (lower left quadrant), early apoptotic cells (lower right quadrant), and late apoptotic cells (upper right quadrant). The proportion of early apoptotic cells with aspirin treatment and without treatment were similar after $48 \mathrm{~h}$ (Fig. 3A). Additionally, there was no obvious difference in cCK-18 levels between treated and untreated cells after 24- or 48-h treatments (Fig. 3B).

Aspirin affects miRNA expression in HuCCT-1 cells. A customized microarray platform was used to analyze the expression of 2,555 miRNAs in aspirin-treated and control HuCCT-1 cells. Treatment with $2.5 \mathrm{mmol} / \mathrm{l}$ aspirin for $48 \mathrm{~h}$ induced the overexpression of eight miRNAs, whereas the expression of six miRNAs was decreased (Table I; Fig. 4). Unsupervised hierarchical clustering analysis was conducted by calculating Pearson's centered correlation coefficient, and the results indicated that differentially expressed miRNAs in aspirin-treated HuCCT-1 cells clustered together. Previous studies have indicated that miR-340-5p has tumor-suppressive properties $(27,28)$, and miR-340-5p exhibited functions in different parts in the KEGG pathway analyses of upregulated miRNAs, which included 'prion diseases', 'microRNA in cancer', 'proteoglycans in cancer', and 'signaling pathways regulating pluripotency of stem cells' as well as others (Fig. 5A). Although the expression of miR-340-5p was not clearly revealed in CCA, it was decreased in most types of cancer (Fig. 5B). The miRNA regulatory network and miRDB database predicted 
HuCCT-1

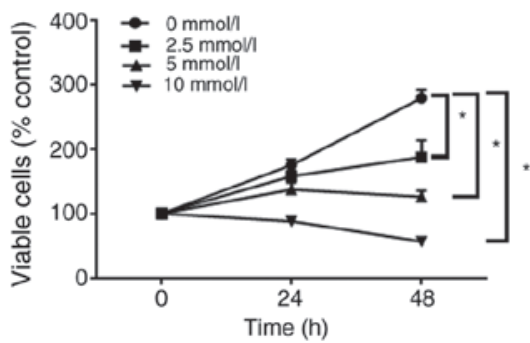

RBE

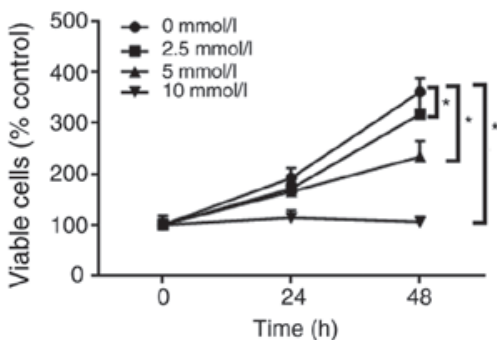

TKKK

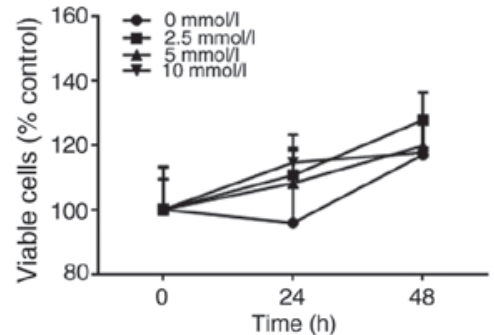

Figure 1. Aspirin inhibits the proliferation of some CCA cells. All cell lines were treated with $0,2.5,5$, or $10 \mathrm{mmol} / 1$ aspirin for 24 or $48 \mathrm{~h}$. The data points represent the mean cell number from three independent cultures, and the error bars represent standard deviations. The antiproliferative effect was significantly higher in cells treated with aspirin treatment for $48 \mathrm{~h}$ than in control cells $(0 \mathrm{mmol} / \mathrm{l})$ as determined by two-way analysis of variance, except for TKKK cells. ${ }^{*} \mathrm{P}<0.01$, vs. the control. CCA, cholangiocarcinoma.

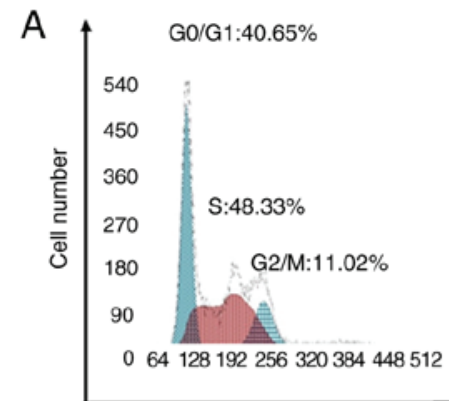

$24 \mathrm{~h}(-)$

B

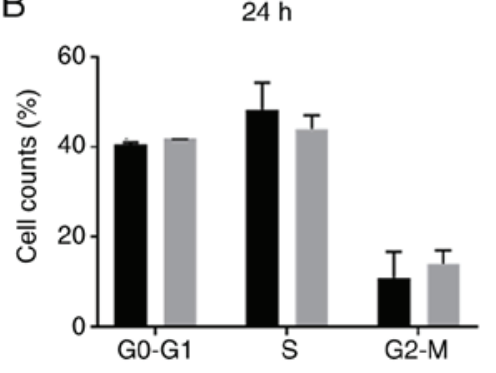

Go/G1:41.81\%

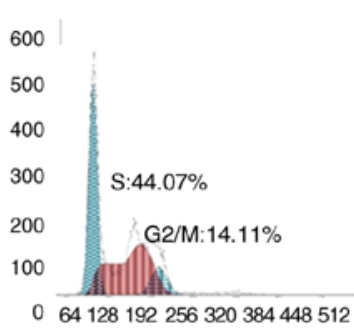

G0/G1:61.32\%

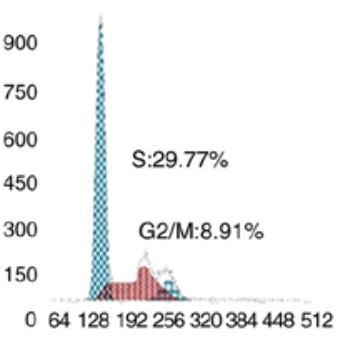

G0/G1:67.20\%

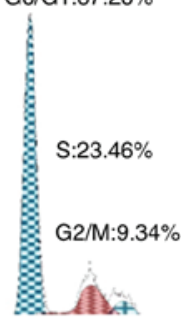

064128192256320384448512

$48 \mathrm{~h}(+)$

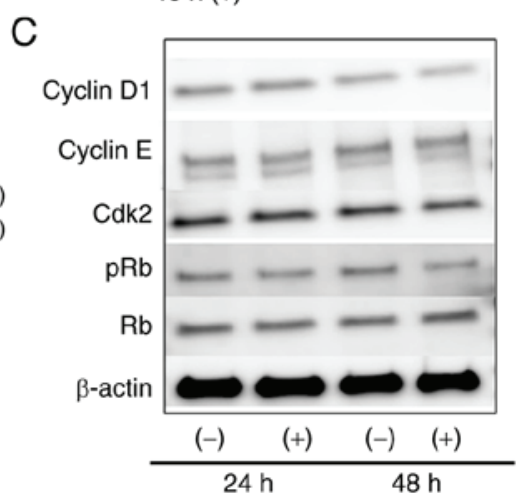

Figure 2. Aspirin causes cell cycle arrest in HuCCT-1 cells. (A) HuCCT-1 cells treated with or without 2.5 mmol/1 aspirin were analyzed by flow cytometry to estimate the proportion of cells in each phase of the cell cycle. (B) Graphical representation of the proportion of cells in each phase of the cell cycle. Aspirin blocked the cell cycle at the $\mathrm{G}_{0} / \mathrm{G}_{1}$ phase. ${ }^{* *} \mathrm{P}<0.01$, vs. the control. (C) Expression of cyclin D1, cyclin E, Cdk2, Rb, and pRb in HuCCT-1 cells 24 and $48 \mathrm{~h}$ after aspirin treatment. $\mathrm{Rb}$, retinoblastoma; $\mathrm{pRb}$, phosphorylated $\mathrm{Rb}$.

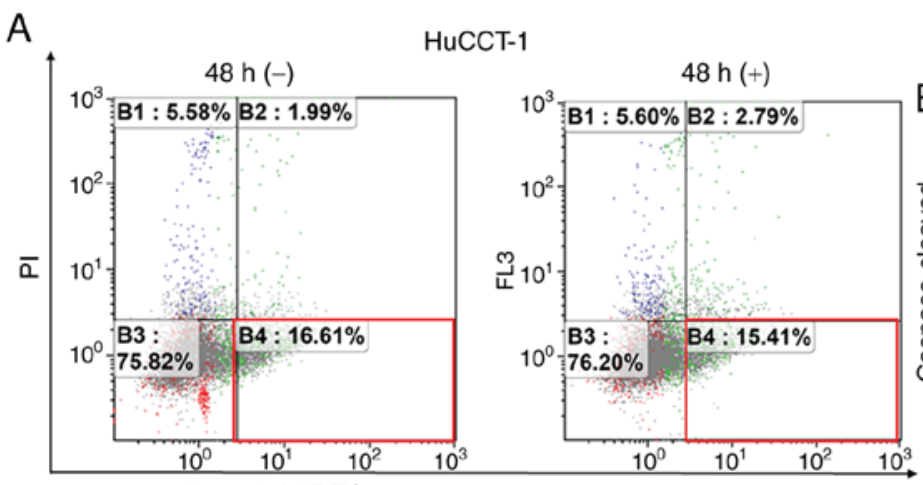

Annexin V-FITC
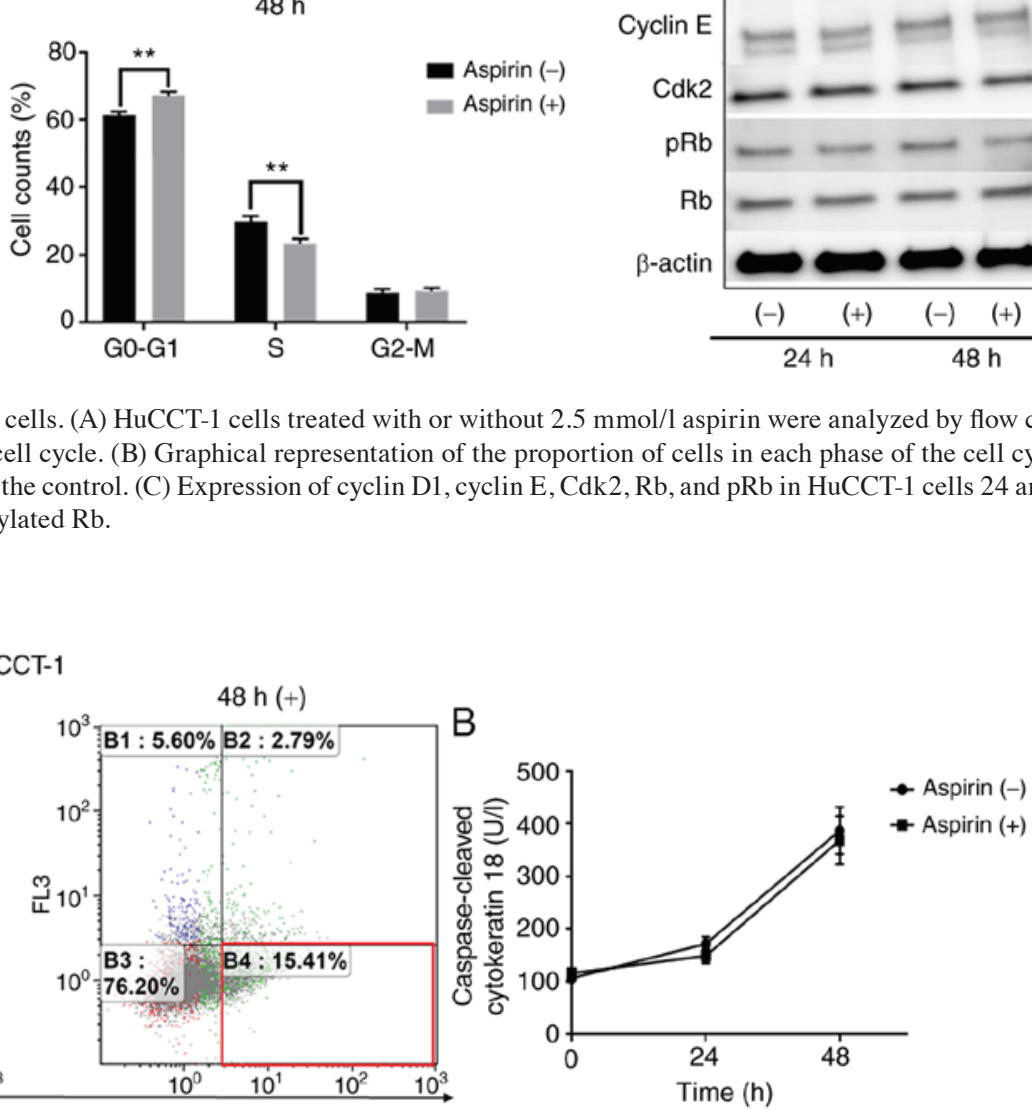

Figure 3. Aspirin does not induce apoptosis in HuCCT-1 cells. (A) Aspirin treatment (2.5 mmol/1 for $48 \mathrm{~h})$ did not alter the proportion of early apoptotic HuCCT-1 cells as determined by flow cytometry. (B) The expression of caspase-cleaved cytokeratin 18 as determined using ELISA after 24 or 48 h of $2.5 \mathrm{mmol} / 1$ aspirin treatment. 
Table I. Statistical results and chromosomal locations of microRNAs in HuCCT-1 cells.

miRNA $\quad$ Fold change (Treated/Untreated) P-value Chromosomal location

A, Upregulated

\begin{tabular}{lccc}
\hline hsa-miR-6504-3p & 3.092 & 0.021 & 16 \\
hsa-miR-4266 & 2.701 & 0.005 & $2 q 13$ \\
hsa-miR-4708-3p & 2.158 & 0.028 & 14 \\
hsa-miR-532-5p & 2.055 & 0.039 & $\mathrm{X}$ \\
hsa-miR-340-5p & 2.029 & 0.039 & 5 \\
hsa-miR-203a-3p & 1.552 & 0.018 & 14 \\
hsa-miR-1180-3p & 1.547 & 0.009 & 17 \\
hsa-miR-146a-5p & 1.522 & 0.022 & 5 \\
\hline
\end{tabular}

B, Downregulated

\begin{tabular}{llll}
\hline hsa-miR-6744-3p & 0.654 & 0.003 & 11 \\
hsa-miR-6752-3p & 0.652 & 0.000 & 11 \\
hsa-miR-6859-5p & 0.640 & 0.041 & $9 \mathrm{q} 34.2$ \\
hsa-miR-4669 & 0.636 & 0.030 & \\
hsa-miR-3607-5p & 0.526 & 0.045 & $10 \mathrm{p} 11.23$ \\
hsa-miR-604 & 0.445 & 0.011 & \\
\hline
\end{tabular}

Cells treated with aspirin that exhibited a fold change $(\mathrm{FC})>1.5, \mathrm{FC}<0.67$, or a P-value $<0.05$ compared with untreated cells are presented.

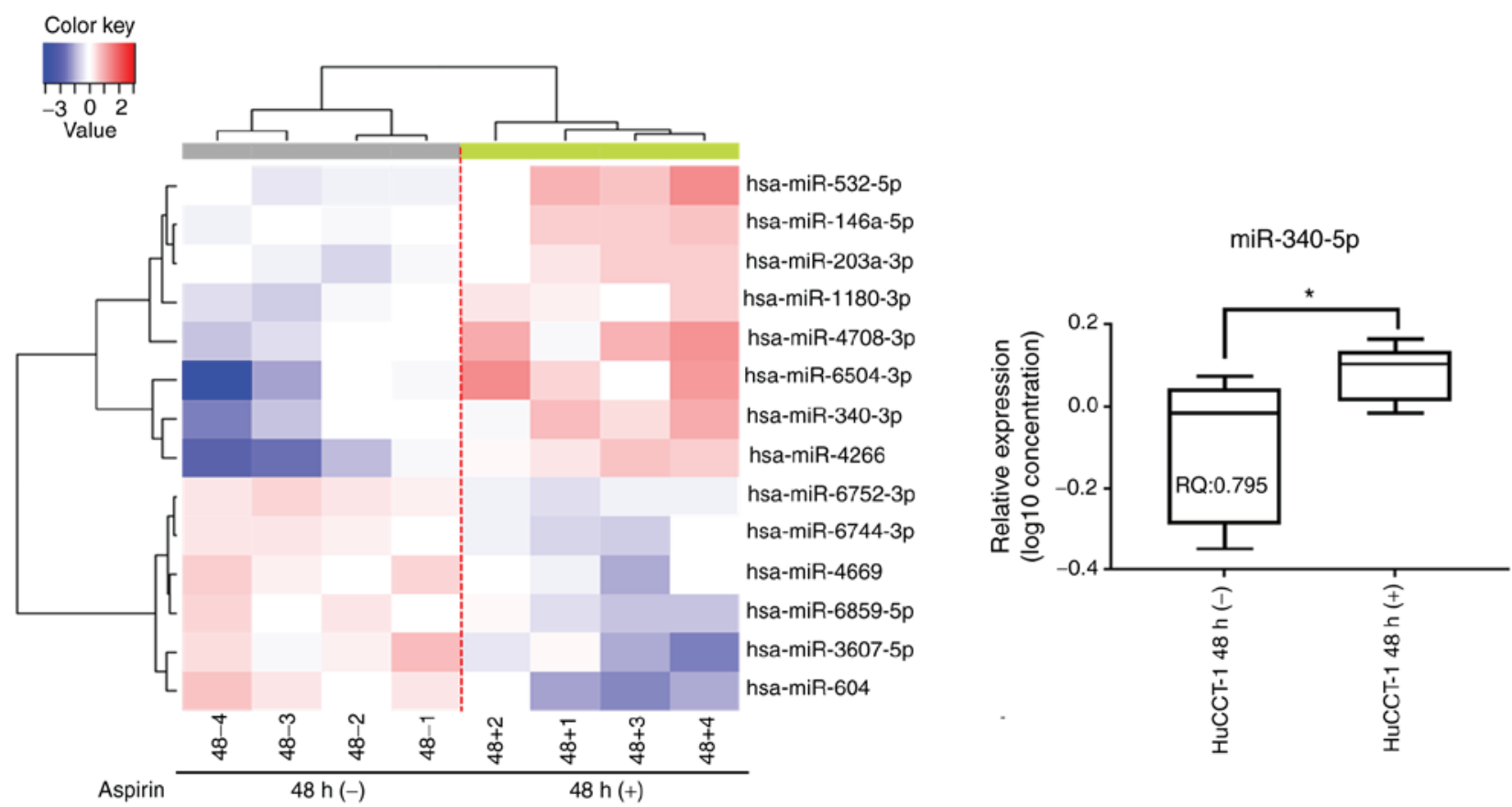

Figure 4. Aspirin affects microRNA expression in HuCCT-1 cells. Hierarchical clustering of the expression profiles of numerous differentially expressed miRNAs from HuCCT-1 cells cultured with or without aspirin. Relative quantification of miRNA following aspirin treatment. miR-340-5p expression was significantly upregulated after aspirin treatment. ${ }^{*} \mathrm{P}<0.05$, vs. the control. The $\log _{10} 2^{-\Delta \Delta \mathrm{Cq}}$ values for microRNAs were used to create the image, and the lines represent averages with interquartile ranges.

that CCND1 may be a target of miR-340-5p (Fig. 5C and D). Thus, it was selected for further study, and RT-qPCR indicated that miR-340-5p levels were significantly upregulated in the aspirin-treated cells compared to the untreated cells (Fig. 4). Numerous other studies have revealed the effects of miRNAs on CCA in recent years (Table II) (29-47). 
A

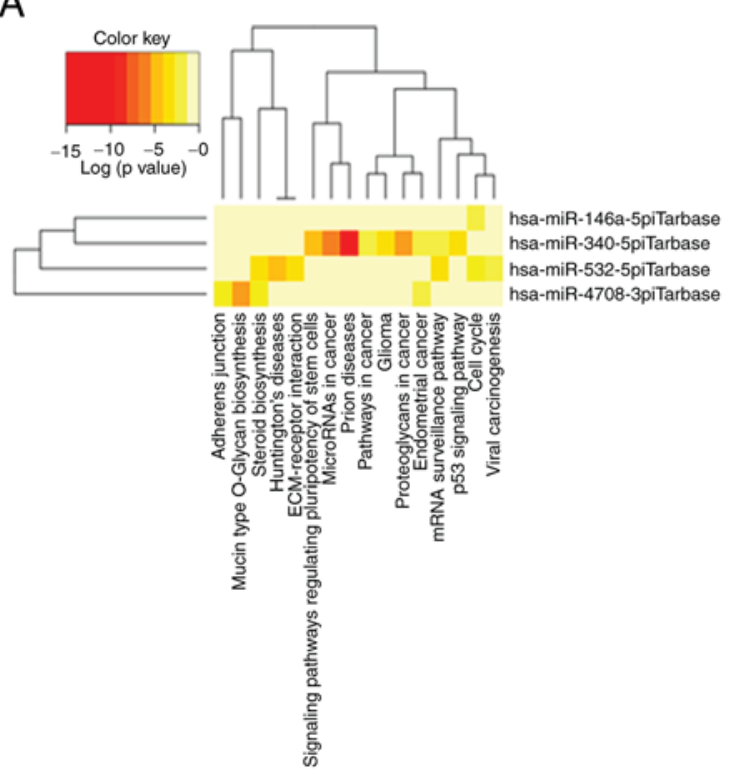

B

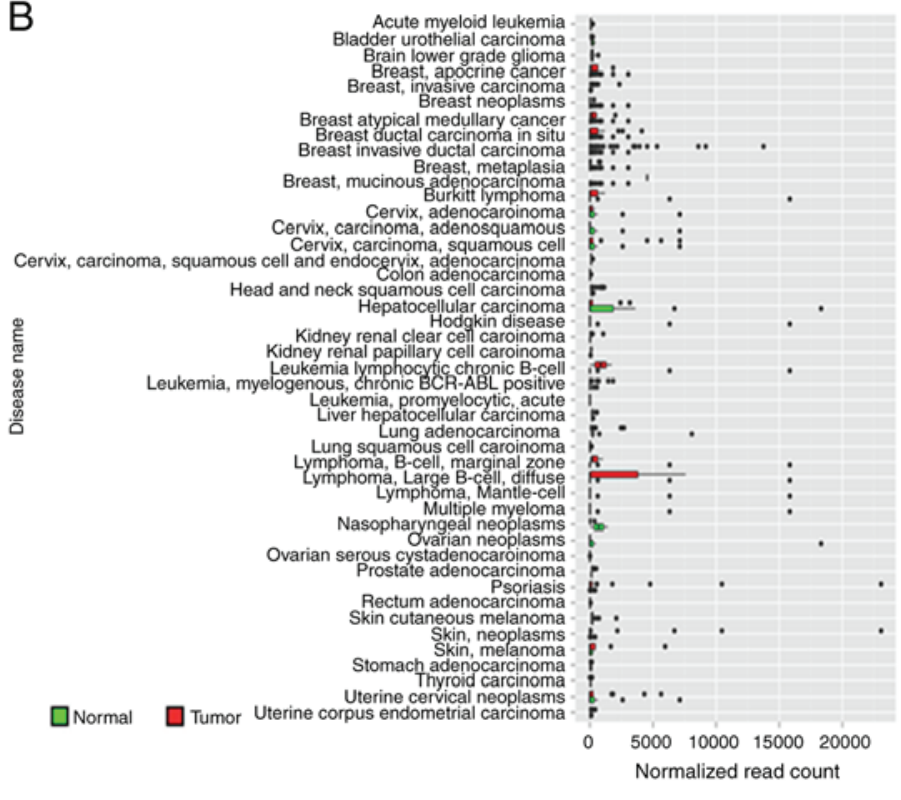

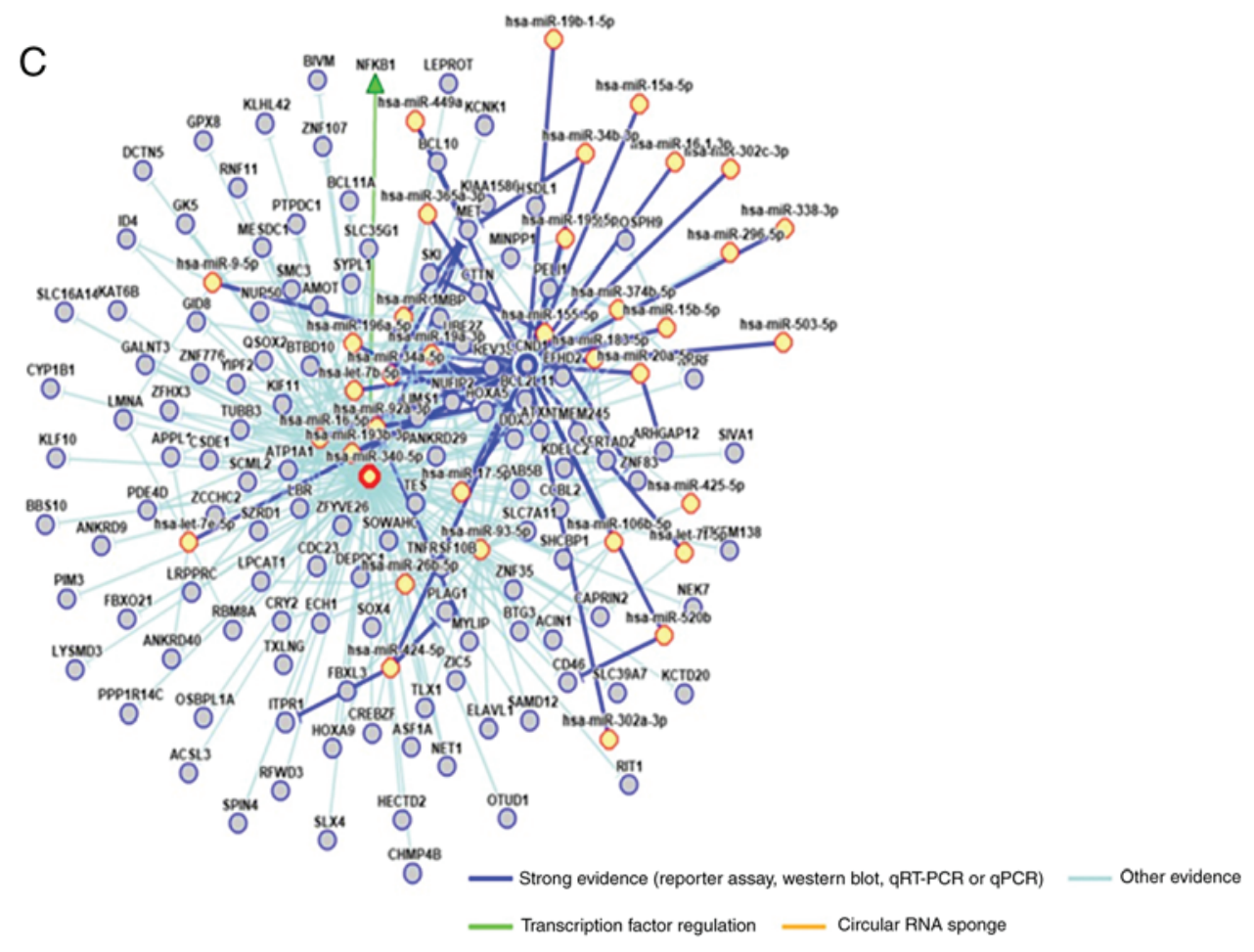

CCND1 3'UTR (584-600)

5' TGTTACTGAA T A TTTCACTG 3 '

i I I I I I I !

miR-340-5p $\quad 3^{\prime}$ UUAUAAAGCAAUGAGACUGAUU 5'

! ' I I ! :

CCND1 3'UTR (1451-1470) 5' ACGTAAATATTTAGTATGAC $\quad 3^{\prime}$

Figure 5. Bioinformatics analysis and the predicted target gene of miR-340-5p. (A) The Kyoto Encyclopedia of Genes and Genomes pathway analyses of upregulated miRNAs. (B) Expression levels of miR-340-5p in related cancer and normal tissue. Compared with normal tissue, the expression of miR-340-5p was revealed to be decreased in most types of cancer. (C) miRNA regulatory network of miR-340-5p. The intensity of evidence between miR-340-5p with predicted target genes and relationships with associated miRNAs are presented in this network. (D) The seed sequence of human miR-340-5p was complementary to the 3'UTR of CCND1. 
Table II. Previous studies examining microRNAs in cholangiocarcinoma.

\begin{tabular}{|c|c|c|c|}
\hline MicroRNA (promoter) & References & MicroRNA (inhibitor) & References \\
\hline $\begin{array}{l}\operatorname{miR}-191 \\
\operatorname{miR}-205-5 p \\
\operatorname{miR}-21 \\
\operatorname{miR}-181 \mathrm{c} \\
\operatorname{miR}-193-3 \mathrm{p} \\
\operatorname{miR}-383\end{array}$ & $\begin{array}{l}\text { Li et al (2017) (29) } \\
\text { Kitdumrongthum et al (2018) (31) } \\
\text { Lampis et al (2018) (33) } \\
\text { Wang et al (2016) (35) } \\
\text { Han et al (2018) (37) } \\
\text { Wan et al (2018) (27) }\end{array}$ & $\begin{array}{l}\text { miR-195 } \\
\text { miR-410 } \\
\text { miR-203 } \\
\text { miR-15a } \\
\text { miR-34a } \\
\text { miR-433 } \\
\text { miR-22 } \\
\text { miR-199a-3p } \\
\text { miR-144 } \\
\text { miR-590-3p } \\
\text { miR-101 } \\
\text { miR-26b-5p } \\
\text { miR-24 } \\
\text { miR-122 } \\
\text { miR-26a } \\
\text { miR-551b-3p }\end{array}$ & $\begin{array}{l}\text { Li et al (2017) (39) } \\
\text { Yang et al (2014) (40) } \\
\text { Zu et al (2017) (41) } \\
\text { Deng et al (2015) (42) } \\
\text { Fan et al (2018) (43) } \\
\text { Ehrlich et al (2017) (44) } \\
\text { Liu et al (2015) (45) } \\
\text { Wang and Lv (2016) (46) } \\
\text { Chang et al (2019) (47) }\end{array}$ \\
\hline
\end{tabular}
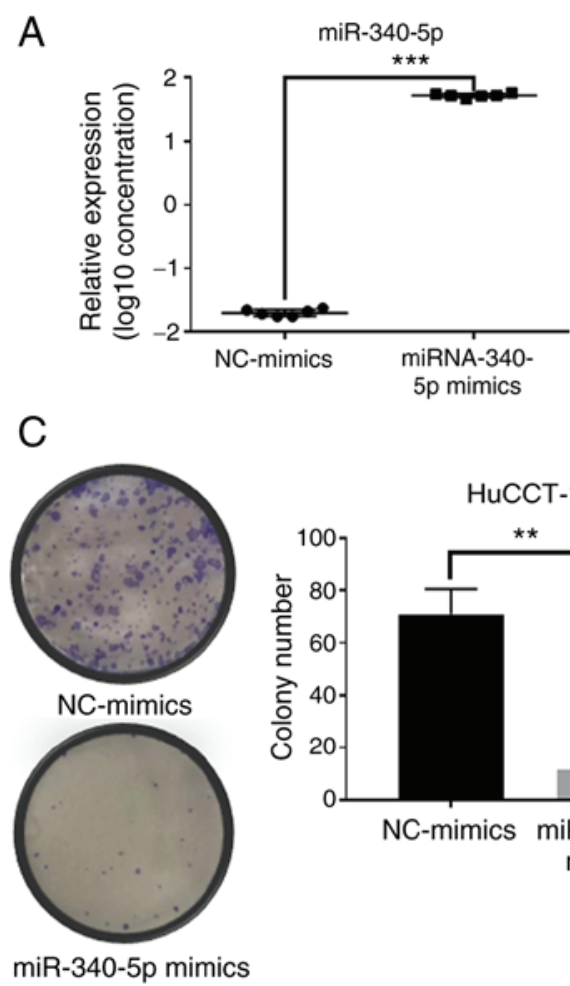

B
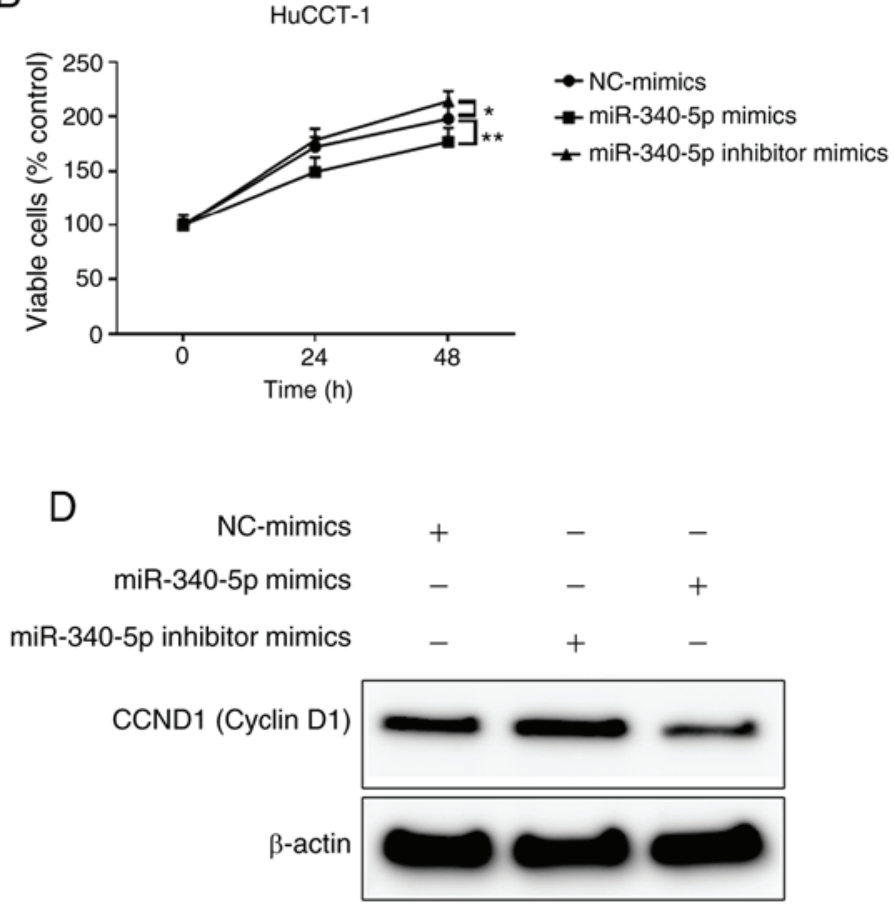

Figure 6. Role of miR-340-5p in HuCCT-1 cells. (A) Relative quantification of miR-340-5p following transfection of miR-340-5p mimics or NC. (B) Cell proliferation in HuCCT-1 cells after transfection of NC-mimics, miR-340-5p mimics, or an miR-340-5p inhibitor. (C) miR-340-5p overexpression inhibited colony formation. (D) The levels of cyclin $\mathrm{D} 1$ after transfection of $\mathrm{NC}$ mimics, miR-340-5p mimics, or an miR-340-5p inhibitor. ${ }^{*} \mathrm{P}<0.05$, ${ }^{* *} \mathrm{P}<0.01$ and ${ }^{* * * *} \mathrm{P}<0.001$, vs. the control. NC, negative control.

miR-340-5p inhibits the proliferation of HuCCT-1 cells and decreases the expression levels of cyclin D1. After transfection of miR-340-5p mimics, miR-340-5p expression was significantly increased in the HuCCT-1 cells (Fig. 6A). Transfection of miR-340-5p mimics decreased proliferation in HuCCT-1 cells (Fig. 6B). Moreover, overexpression of miR-340-5p decreased the levels of cyclin D1, whereas inhibition induced increased cyclin D1 levels (Fig. 6D). The colony formation assay indicated that overexpression of miR-340-5p decreased the cell proliferation ability of HuCCT-1 cells (Fig. 6C). Therefore, increasing the levels of miR-340-5p inhibited cyclin D1 expression and decreased the cell proliferation ability. 


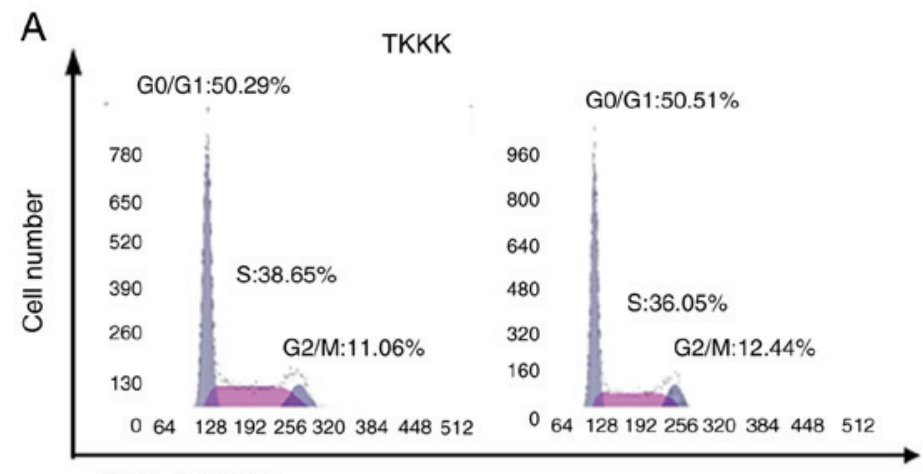

DNA content

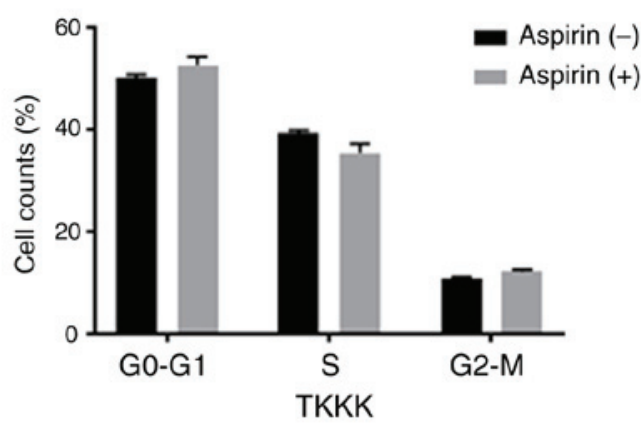

$48 \mathrm{~h}(-)$

B

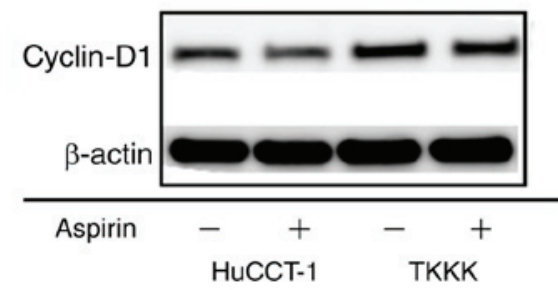

$48 \mathrm{~h}(+)$
C

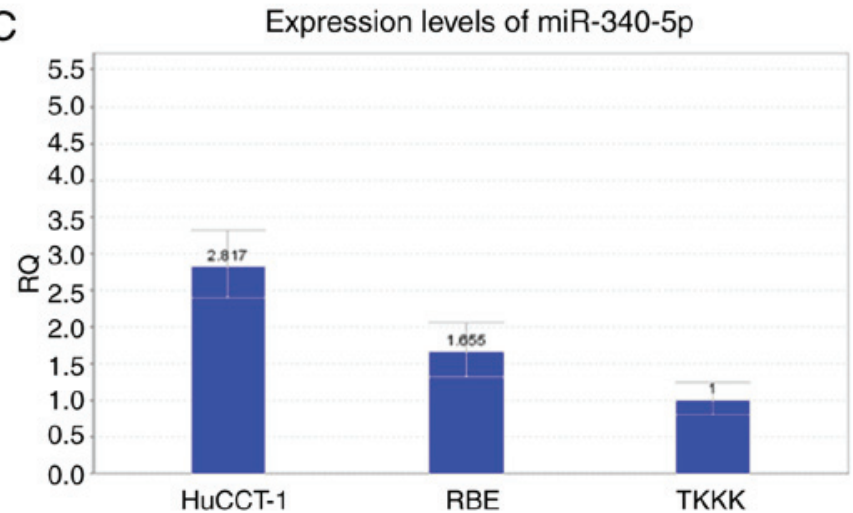

Figure 7. Comparison of the cell cycle and miR-340-5p in aspirin-nonresponsive TKKK cells and aspirin-responsive HuCCT1 cells. (A) Left image: TKKK cells treated with or without $2.5 \mathrm{mmol} / \mathrm{l}$ aspirin and analyzed by flow cytometry to estimate the proportion of cells in each phase of the cell cycle. Right image: Graphical representation of the proportion of cells in each phase of the cell cycle. (B) Expression of cyclin D1 in HuCCT-1 cells and TKKK cells after $48 \mathrm{~h}$ of aspirin treatment. (C) Relative quantification of miR-340-5p in cholangiocarcinoma cell lines.

A

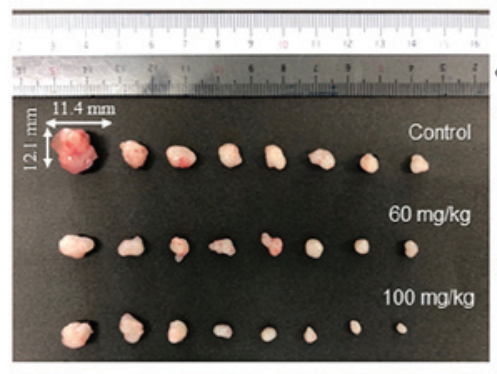

C

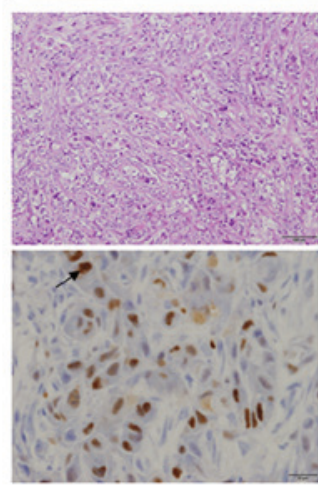

Control

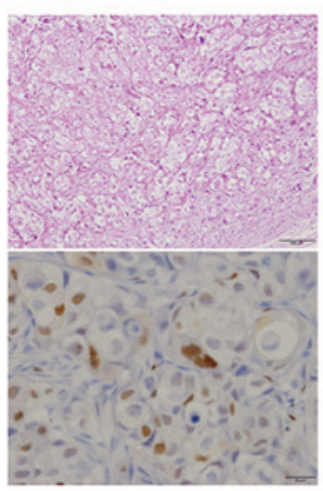

$60 \mathrm{mg} / \mathrm{kg}$
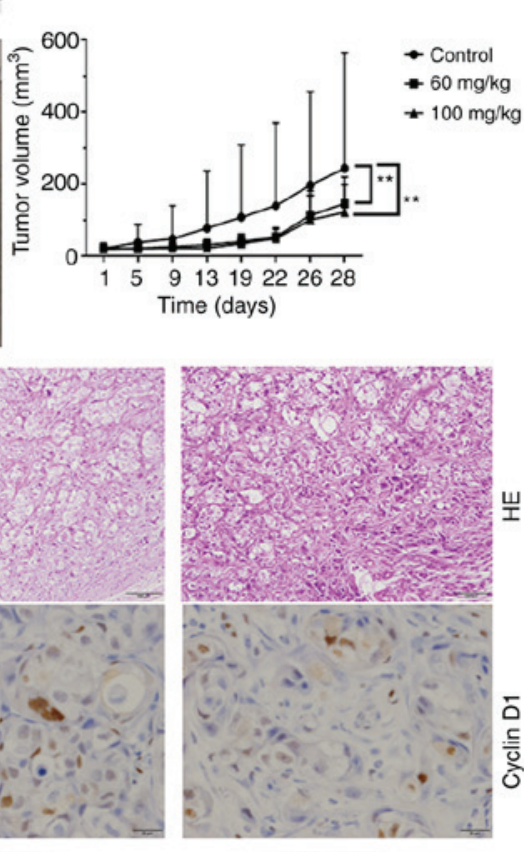

$100 \mathrm{mg} / \mathrm{kg}$
B
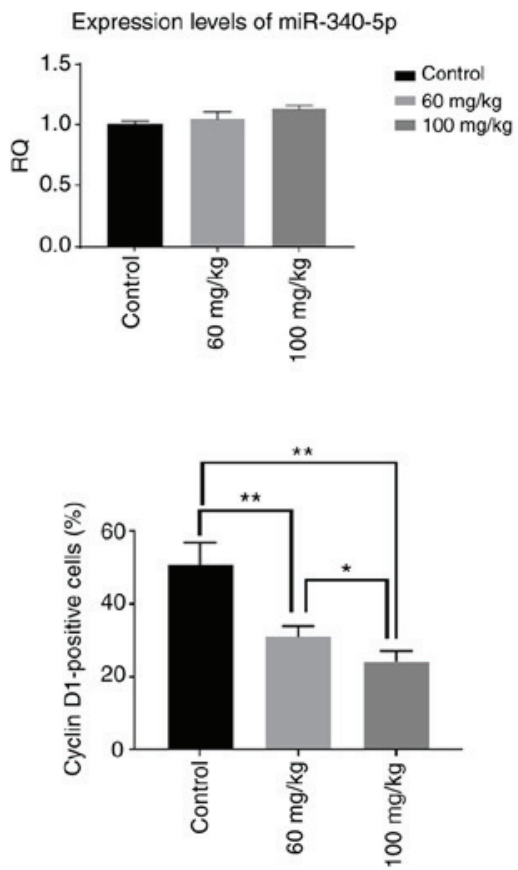

Figure 8. Aspirin inhibits the growth of HuCCT-1 cell xenografts in nude mice. (A) The tumors were significantly smaller in aspirin-treated mice than in vehicle-treated mice. Each point represents the mean \pm standard deviation of 10 animals. ${ }^{* *} \mathrm{P}<0.01$ by mixed analysis of variance. (B) Relative quantification of miR-340-5p in tumor tissue of the three groups of xenografted mice. (C) Left image: H\&E-stained images of the xenografted tumor tissues between the aspirin-treated and control mice (scale bar, $100 \mu \mathrm{m}$ ). Immunohistochemical staining of cyclin D1 between the aspirin-treated and control mice (scale bar, $20 \mu \mathrm{m})$. Right image: Cyclin D1-positive cells in the aspirin-treated groups were reduced in number compared with the control group as determined by one-way analysis of variance. ${ }^{*} \mathrm{P}<0.05$ and ${ }^{* *} \mathrm{P}<0.01$. H\&E, hematoxylin and eosin. 
Aspirin-nonresponsive TKKK cells express low levels of $m i R-340-5 p$. As the CCA cell line TKKK did not exhibit response to aspirin, the cell cycle progression in TKKK cells as compared to HuCCT-1 cells was assessed. Forty-eight hours of aspirin treatment in TKKK cells revealed no obvious difference in the proportion of cells in each phase of the cell cycle (Fig. 7A). In addition, the levels of cyclin D1 were not significantly altered (Fig. 7B). Relative quantification of miR-340-5p was assessed in all cell lines (Fig. 7C). Expression was lowest in TKKK cells, which may indicate that cell lines with high expression of miR-340-5p are more sensitive to cell cycle arrest with aspirin treatment.

Aspirin inhibits tumor proliferation in vivo. Based on the results obtained from in vitro studies, the effect of aspirin in an in vivo model of CCA was assessed. Nude mice were injected subcutaneously with HuCCT-1 cells followed by intraperitoneal injection of aspirin. The present results revealed that tumor growth was significantly inhibited in mice treated with aspirin compared to untreated mice $(\mathrm{P}<0.05)$ (Fig. 8A). No mice succumbed during the observation period. Expression levels of miR-340-5p in tumor tissue were not significantly different, although the RQ was slightly increased in the two aspirin-treated groups (Fig. 8B). H\&E-stained images of the xenografted tumor tissues revealed no significant histopathological differences between the aspirin-treated and control mice. Immunohistochemical staining of cyclin D1 indicated that cyclin D1-positive cells in the aspirin-treated groups were reduced in number compared with the control group (Fig. 8C).

\section{Discussion}

CCA is an aggressive cancer with high mortality and poor prognosis that accounts for approximately $3 \%$ of gastrointestinal malignancies (8). The 5-year survival rate of CCA is only $10 \%$, and the median survival is 24 months (48). Initial analysis revealed that aspirin use was associated with a reduced iCCA risk in men (HR=0.64,95\% CI=0.42-0.98) (49). Subsequent analysis has revealed that aspirin use has a significant inverse association with the development of all three CCA subtypes and leads to an approximately 3 -fold reduction in CCA risk (13). This is thought to be due to the anti-inflammatory effect of aspirin. In the present study, we further elucidated the mechanism of the effect of aspirin on CCA. To the best of our knowledge, the present study is the first study revealing that aspirin inhibits the proliferation of CCA cells in vivo.

The anti-inflammatory dose of aspirin varies from 0.5-2.5 mM (50); therefore, relying on data from the antiproliferation assay, $2.5 \mathrm{mM}$ was selected as the concentration of aspirin, which does not have off-target cytotoxicity. It was observed that aspirin inhibited the proliferation of CCA cells (HuCCT-1 and RBE) and induced cell cycle arrest (HuCCT-1) at the $\mathrm{G}_{0} / \mathrm{G}_{1}$ phase, which was correlated with a marked decrease in the expression of cyclin D1. Aspirin also decreased the phosphorylation of $\mathrm{Rb}$. The expression of cell cycle-related molecules is related to cancer progression and prognosis (51), and aspirin has been revealed to inhibit the expression of cyclin D1 in other types of cancer, such as oral squamous cell carcinoma (52) and glioblastoma multiforme (53). To determine whether aspirin induced apoptosis, HuCCT-1 cells were treated with $2.5 \mathrm{mM}$ aspirin and analyzed using FCM; the levels of cCK18 were also measured. However, there was no evidence that aspirin induced apoptosis in HuCCT-1 cells. These data indicated that aspirin inhibited CCA cell proliferation mainly through cell cycle arrest. However, aspirin has also been revealed to induce apoptosis in numerous types of cancers (52-55); this discrepancy could be due to differences in the properties of different types of cancers.

miRNAs are short, noncoding, endogenous, single-stranded RNA molecules 19-25 nucleotides in length that regulate target gene expression (56). They are known to regulate the development and progression of various cancers (57). A miRNA expression array was used to identify the miRNAs associated with the antitumor effects of aspirin. miR-340-5p that was significantly upregulated in response to aspirin treatment in cells, was not significantly different in tumor tissue, although the relative quantification (RQ) was slightly increased in the two aspirin-treated groups. Recent studies have indicated that miR-340-5p inhibited non-small cell lung cancer cell growth and metastasis by targeting ZNF503 (58) and suppressed osteosarcoma development via targeting STAT3 (59). In the present study, overexpression of miR-340-5p inhibited proliferation in HuCCT-1 cells. In addition, overexpression of miR-340-5p decreased the levels of cyclin D1. The predicted sequence from the miRDB database and bioinformatics analysis indicated that cyclin D1 may be an miR-340-5p target, and miR-340-5p overexpression decreased cyclin D1 levels in cells; immunohistochemical staining indicated that cyclin D1-positive cells in aspirin-treated mice were reduced compared with control mice. Therefore, it is theorized that aspirin works partially through the miR-340-5p/cyclin D1 axis to inhibit HuCCT-1 cell proliferation.

In the present study, aspirin treatment had no effect on TKKK cells. To investigate the difference between TKKK cells and HuCCT-1 cells, FCM was used to analyze changes in the cell cycle with aspirin treatment. Aspirin did not induce $\mathrm{G}_{0} / \mathrm{G}_{1}$ arrest in TKKK cells, and there was no difference in the levels of cyclin D1 after $48 \mathrm{~h}$ of treatment. In addition, the relative levels of miR-340-5p were assessed in all cell lines, and TKKK cells had the lowest expression. Therefore, aspirin may not suppress proliferation in TKKK cells because it cannot utilize the miR-340-5p/cyclin D1 axis.

In the present in vivo model, aspirin inhibited the growth of subcutaneous CCA tumors in athymic nude mice. In accordance with the in vitro results and previous studies $(23,60)$, in the in vivo experiment, the tumor volumes in both treatment groups (low-dosage and high-dosage) were significantly decreased compared with the tumor volume in the control group. However, there was no obvious difference in tumor volume between the low-dosage and high-dosage groups; long-term treatment may be required to see a difference based on dosage.

In conclusion, the present study indicated that aspirin inhibited cell proliferation and tumor growth in some CCA cell lines by inducing $G_{0} / G_{1}$ phase cell cycle arrest, and the underlying mechanism may partially be through the miR-340-5p/cyclin D1 axis to induce cell cycle arrest. 


\section{Acknowledgements}

We thank Ms. Kayo Hirose, Ms. Keiko Fujikawa, Ms. Miwako Watanabe, Ms. Megumi Okamura, and Ms. Fuyuko Kokado at the Department of Gastroenterology and Neurology of Kagawa University (Kagawa, Japan) for their assistance.

\section{Funding}

No funding was received.

\section{Availability of data and materials}

All data supporting the conclusions of the present study have been documented in this study.

\section{Authors' contributions}

TS, AM, HK and TM conceived and designed the experiments. TS, HI, JG, NN, SL, MN, HY, TN, KO, YS and KF analyzed and interpreted the data. TS performed the experiments. TS wrote, reviewed and edited the manuscript. TM reviewed and edited the manuscript for important intellectual content. All authors reviewed, read and approved the final manuscript.

\section{Ethics approval and consent to participate}

All experimental protocols were approved (approval no. 18674) by the Institutional Review Board of the Department of Laboratory Animal Science of Kagawa University (Kawaga, Japan).

\section{Patient consent for publication}

Not applicable.

\section{Competing interests}

The authors declare that they have no competing interests.

\section{References}

1. Patel T: Increasing incidence and mortality of primary intrahepatic cholangiocarcinoma in the United States. Hepatology 33: 1353-1357, 2001.

2. Xiao J, Zhu J, Liu Z, Wan R, Li Y and Xiao W: Role of surgical treatment for hepatolithiasis-associated intrahepatic cholangiocarcinoma: A retrospective study in a single institution. J Cancer Res Ther 13: 756-760, 2017.

3. Arbelaiz A, Azkargorta M, Krawczyk M, Santos-Laso A, Lapitz A, Perugorria MJ, Erice O, Gonzalez E, Jimenez-Agüero R, Lacasta A, et al: Serum extracellular vesicles contain protein biomarkers for primary sclerosing cholangitis and cholangiocarcinoma. Hepatology 66: 1125-1143, 2017.

4. Kim TS, Pak JH, Kim JB and Bahk YY: Clonorchis sinensis, an oriental liver fluke, as a human biological agent of cholangiocarcinoma: A brief review. BMB Rep 49: 590-597, 2016.

5. Jang MH, Lee YJ and Kim H: Intrahepatic cholangiocarcinoma arising in Caroli's disease. Clin Mol Hepatol 20: 402-405, 2014.

6. Shi Y, Jiang Z, Yang Y, Zheng P, Wei H, Lin Y, Lv G and Yang Q: Clonorchis sinensis infection and co-infection with the hepatitis B virus are important factors associated with cholangiocarcinoma and hepatocellular carcinoma. Parasitol Res 116: 2645-2649, 2017.

7. Blechacz B: Cholangiocarcinoma: Current knowledge and new developments. Gut Liver 11: 13-26, 2017.
8. Razumilava N and Gores GJ: Cholangiocarcinoma. Lancet 383: 2168-2179, 2014.

9. Zhang H, Yang T, Wu M and Shen F: Intrahepatic cholangiocarcinoma: Epidemiology, risk factors, diagnosis and surgical management. Cancer Lett 379: 198-205, 2016.

10. Ng K, Meyerhardt JA, Chan AT, Sato K, Chan JA, Niedzwiecki D, Saltz LB, Mayer RJ, Benson AB III, Schaefer PL, et al: Aspirin and COX-2 inhibitor use in patients with stage III colon cancer. J Natl Cancer Inst 107: 345, 2014.

11. Barron TI, Flahavan EM, Sharp L, Bennett K and Visvanathan K: Recent prediagnostic aspirin use, lymph node involvement, and 5-year mortality in women with stage I-III breast cancer: A nationwide population-based cohort study. Cancer Res 74: 4065-4077, 2014

12. Simon TG, Ma Y, Ludvigsson JF, Chong DQ, Giovannucci EL, Fuchs CS, Meyerhardt JA, Corey KE, Chung RT, Zhang X and Chan AT: Association between aspirin use and risk of hepatocellular carcinoma. JAMA Oncol 4: 1683-1690, 2018.

13. Choi J, Ghoz HM, Peeraphatdit T, Baichoo E, Addissie BD, Harmsen WS, Therneau TM, Olson JE, Chaiteerakij R and Roberts LR: Aspirin use and the risk of cholangiocarcinoma. Hepatology 64: 785-796, 2016.

14. Guenzle J, Garrelfs NWC, Goeldner JM and Weyerbrock A: Cyclooxygenase (COX) inhibition by acetyl salicylic acid (ASA) enhances antitumor effects of nitric oxide in glioblastoma in vitro. Mol Neurobiol 56: 6046-6055, 2019.

15. Henry WS, Laszewski T, Tsang T, Beca F, Beck AH, McAllister SS and Toker A: Aspirin suppresses growth in PI3K-mutant breast cancer by activating AMPK and inhibiting mTORC1 signaling. Cancer Res 77: 790-801, 2017.

16. Liu YX, Feng JY, Sun MM, Liu BW, Yang G, Bu YN, Zhao M, Wang TJ, Zhang WY, Yuan HF and Zhang XD: Aspirin inhibits the proliferation of hepatoma cells through controlling GLUT1-mediated glucose metabolism. Acta Pharmacol Sin 40: 122-132, 2019.

17. Huang Z, Fang W, Liu W, Wang L, Liu B, Liu S and Liu S: Aspirin induces Beclin-1-dependent autophagy of human hepatocellular carcinoma cell. Eur J Pharmacol 823: 58-64, 2018.

18. Raza H, John A and Benedict S: Acetylsalicylic acid-induced oxidative stress, cell cycle arrest, apoptosis and mitochondrial dysfunction in human hepatoma HepG2 cells. Eur J Pharmacol 668: 15-24, 2011.

19. Pavlovic N, Rani B, Gerwins P and Heindryckx F: Platelets as key factors in hepatocellular carcinoma. Cancers (Basel) 11: $1022,2019$.

20. Malehmir M, Pfister D, Gallage S, Szydlowska M, Inverso D, Kotsiliti E, Leone V, Peiseler M, Surewaard BGJ, Rath D, et al: Platelet GPIb $\alpha$ is a mediator and potential interventional target for NASH and subsequent liver cancer. Nat Med 25: 641-655, 2019.

21. Livak KJ and Schmittgen TD: Analysis of relative gene expression data using real-time quantitative PCR and the 2(-Delta Delta C(T)) method. Methods 25: 402-408, 2001.

22. Kanehisa M, Sato Y, Furumichi M, Morishima K and Tanabe M: New approach for understanding genome variations in KEGG. Nucleic Acids Res 47: D590-D595, 2019.

23. Vlachos IS, Zagganas K, Paraskevopoulou MD, Georgakilas G, Karagkouni D, Vergoulis T, Dalamagas T and Hatzigeorgiou AG: DIANA-miRPath v3.0: Deciphering microRNA function with experimental support. Nucleic Acids Res 43: W460-W466, 2015.

24. Cho S, Jang I, Jun Y, Yoon S, Ko M, Kwon Y, Choi I, Chang H, Ryu D, Lee B, et al: MiRGator v3.0: A microRNA portal for deep sequencing, expression profiling and mRNA targeting. Nucleic Acids Res 41 (Database issue): D252-D257, 2013.

25. Huang HY, Lin YC, Li J, Huang KY, Shrestha S, Hong HC, Tang Y, Chen YG, Jin CN, Yu Y, et al: miRTarBase 2020: Updates to the experimentally validated microRNA-target interaction database. Nucleic Acids Res 48: D148-D154, 2020.

26. Pietenpol JA and Stewart ZA: Cell cycle checkpoint signaling: Cell cycle arrest versus apoptosis. Toxicology 181-182: 475-481, 2002.

27. Wan P, Chi X, Du Q, Luo J, Cui X, Dong K, Bing Y, Heres C and Geller DA: miR-383 promotes cholangiocarcinoma cell proliferation, migration, and invasion through targeting IRF1. J Cell Biochem 119: 9720-9729, 2018.

28. Mansini AP, Lorenzo Pisarello MJ, Thelen KM, Cruz-Reyes M, Peixoto E, Jin S, Howard BN, Trussoni CE, Gajdos GB, LaRusso NF, et al: MicroRNA (miR)-433 and miR-22 dysregulations induce histone-deacetylase- 6 overexpression and ciliary loss in cholangiocarcinoma. Hepatology 68: 561-573, 2018. 
29. Li H, Zhou ZQ, Yang ZR, Tong DN, Guan J, Shi BJ, Nie J, Ding XT, Li B, Zhou GW and Zhang ZY: MicroRNA-191 acts as a tumor promoter by modulating the TET1-p53 pathway in intrahepatic cholangiocarcinoma. Hepatology 66: 136-151, 2017.

30. Li L, Piontek K, Ishida M, Fausther M, Dranoff JA, Fu R, Mezey E, Gould SJ, Fordjour FK, Meltzer SJ, et al: Extracellular vesicles carry microRNA-195 to intrahepatic cholangiocarcinoma and improve survival in a rat model. Hepatology 65: 501-514, 2017.

31. Kitdumrongthum S, Metheetrairut C, Charoensawan V, Ounjai P, Janpipatkul K, Panvongsa W, Weerachayaphorn J, Piyachaturawat $\mathrm{P}$ and Chairoungdua A: Dysregulated microRNA expression profiles in cholangiocarcinoma cell-derived exosomes. Life Sci 210: 65-75, 2018.

32. Palumbo T, Poultsides GA, Kouraklis G, Liakakos T, Drakaki A, Peros G, Hatziapostolou M and Iliopoulos D: A functional microRNA library screen reveals miR-410 as a novel anti-apoptotic regulator of cholangiocarcinoma. BMC Cancer 16: 353, 2016

33. Lampis A, Carotenuto P, Vlachogiannis G, Cascione L, Hedayat S, Burke R, Clarke P, Bosma E, Simbolo M, Scarpa A, et al: MIR21 drives resistance to heat shock protein 90 inhibition in cholangiocarcinoma. Gastroenterology 154: 1066-1079.e5, 2018.

34. Li J, Gao B, Huang Z, Duan T, Li D, Zhang S, Zhao Y, Liu L, Wang Q, Chen Z and Cheng K: Prognostic significance of microRNA-203 in cholangiocarcinoma. Int J Clin Exp Pathol 8: 9512-9516, 2015

35. Wang J, Xie C, Pan S, Liang Y, Han J, Lan Y, Sun J, Li K, Sun B, Yang $\mathrm{G}$, et al: $\mathrm{N}$-myc downstream-regulated gene 2 inhibits human cholangiocarcinoma progression and is regulated by leukemia inhibitory factor/MicroRNA-181c negative feedback pathway. Hepatology 64: 1606-1622, 2016.

36. Utaijaratrasmi $\mathrm{P}$, Vaeteewoottacharn $\mathrm{K}$, Tsunematsu $\mathrm{T}$, Jamjantra P, Wongkham S, Pairojkul C, Khuntikeo N, Ishimaru N, Sirivatanauksorn Y, Pongpaibul A, et al: The microRNA-15a-PAI-2 axis in cholangiocarcinoma-associated fibroblasts promotes migration of cancer cells. Mol Cancer 17: 10, 2018.

37. Han YL, Yin JJ and Cong JJ: Downregulation of microRNA-193-3p inhibits the progression of intrahepatic cholangiocarcinoma cells by upregulating TGFBR3. Exp Ther Med 15: 4508-4514, 2018.

38. Han Y, Meng F, Venter J, Wu N, Wan Y, Standeford H, Francis H, Meininger C, Greene J Jr, Trzeciakowski JP, et al: miR-34a-dependent overexpression of Perl decreases cholangiocarcinoma growth. J Hepatol 64: 1295-1304, 2016.

39. Li Q, Xia X, Ji J, Ma J, Tao L, Mo L and Chen W: MiR-199a-3p enhances cisplatin sensitivity of cholangiocarcinoma cells by inhibiting mTOR signaling pathway and expression of MDR1. Oncotarget 8: 33621-33630, 2017.

40. Yang R, Chen Y, Tang C, Li H, Wang B, Yan Q, Hu J and Zou S: MicroRNA-144 suppresses cholangiocarcinoma cell proliferation and invasion through targeting platelet activating factor acetylhydrolase isoform 1b. BMC Cancer 14: 917, 2014.

41. Zu C, Liu S, Cao W, Liu Z, Qiang H, Li Y, Cheng C, Ji L, Li J and Li J: MiR-590-3p suppresses epithelial-mesenchymal transition in intrahepatic cholangiocarcinoma by inhibiting SIP1 expression. Oncotarget 8: 34698-34708, 2017

42. Deng G, Teng Y, Huang F, Nie W, Zhu L, Huang W, andXu H: MicroRNA-101 inhibits the migration and invasion of intrahepatic cholangiocarcinoma cells via direct suppression of vascular endothelial growth factor-C. Mol Med Rep 12: 7079-7085, 2015.

43. Fan F, Lu J, Yu W, Zhang Y, Xu S, Pang L and Zhu B: MicroRNA-26b-5p regulates cell proliferation, invasion and metastasis in human intrahepatic cholangiocarcinoma by targeting S100A7. Oncol Lett 15: 386-392, 2018

44. Ehrlich L, Hall C, Venter J, Dostal D, Bernuzzi F, Invernizzi P, Meng F, Trzeciakowski JP, Zhou T, Standeford H, et al: miR-24 inhibition increases menin expression and decreases cholangiocarcinoma proliferation. Am J Pathol 187: 570-580, 2017.
45. Liu N, Jiang F, He TL, Zhang JK, Zhao J, Wang C, Jiang GX, Cao LP, Kang PC, Zhong XY, et al: The roles of MicroRNA-122 overexpression in inhibiting proliferation and invasion and stimulating apoptosis of human cholangiocarcinoma cells. Sci Rep 5: 16566, 2015.

46. Wang $\mathrm{P}$ and Lv L: miR-26a induced the suppression of tumor growth of cholangiocarcinoma via KRT19 approach. Oncotarget 7: 81367-81376, 2016.

47. Chang W, Wang Y, Li W, Shi L and Geng Z: MicroRNA-551b-3p inhibits tumour growth of human cholangiocarcinoma by targeting Cyclin D1. J Cell Mol Med 23: 4945-4954, 2019.

48. Rizvi S and Gores GJ: Pathogenesis, diagnosis, and management of cholangiocarcinoma. Gastroenterology 145: 1215-1229, 2013.

49. Petrick JL, Sahasrabuddhe VV, Chan AT, Alavanja MC, Beane-Freeman LE, Buring JE, Chen J, Chong DQ, Freedman ND, Fuchs CS, et al: NSAID use and risk of hepatocellular carcinoma and intrahepatic cholangiocarcinoma: The liver cancer pooling project. Cancer Prev Res (Phila) 8: 1156-1162, 2015.

50. Dovizio M, Bruno A, Tacconelli S and Patrignani P: Mode of action of aspirin as a chemopreventive agent. Recent Results Cancer Res 191: 39-65, 2013.

51. Masaki T, Shiratori Y, Rengifo W, Igarashi K, Yamagata M, Kurokohchi K, Uchida N, Miyauchi Y, Yoshiji H, Watanabe S, et al: Cyclins and cyclin-dependent kinases: Comparative study of hepatocellular carcinoma versus cirrhosis. Hepatology 37: 534-543, 2003

52. Zhang X, Feng H, Li Z, Guo J and Li M: Aspirin is involved in the cell cycle arrest, apoptosis, cell migration, and invasion of oral squamous cell carcinoma. Int J Mol Sci 19: 2029, 2018

53. Pozzoli G, Marei HE, Althani A, Boninsegna A, Casalbore P, Marlier LNJL, Lanzilli G, Zonfrillo M, Petrucci G, Rocca B, et al: Aspirin inhibits cancer stem cells properties and growth of glioblastoma multiforme through Rb1 pathway modulation. J Cell Physiol: Jan 30, 2019 (Epub ahead of print).

54. Hossain MA, Kim DH, Jang JY, Kang YJ, Yoon JH, Moon JO, Chung HY, Kim GY, Choi YH, Copple BL and Kim ND: Aspirin induces apoptosis in vitro and inhibits tumor growth of human hepatocellular carcinoma cells in a nude mouse xenograft model. Int J Oncol 40: 1298-1304. 2012.

55. Choi BH, Chakraborty G, Baek K and Yoon HS: Aspirin-induced $\mathrm{Bcl}-2$ translocation and its phosphorylation in the nucleus trigger apoptosis in breast cancer cells. Exp Mol Med 45: e47, 2013.

56. Lu TX and Rothenberg ME: MicroRNA. J Allergy Clin Immunol 141: 1202-1207, 2018.

57. Paliouras AR, Monteverde T and Garofalo M: Oncogene-induced regulation of microRNA expression: Implications for cancer initiation, progression and therapy. Cancer Lett 421: 152-160, 2018.

58. Lu G and Zhang Y: MicroRNA-340-5p suppresses non-small cell lung cancer cell growth and metastasis by targeting ZNF503. Cell Mol Biol Lett 24: 34, 2019.

59. Rongxin S, Pengfei L, Li S, Xiaochen $J$ and Yihe $H$ : MicroRNA-340-5p suppresses osteosarcoma development by down-regulating the $\mathrm{Wnt} / \beta$-catenin signaling pathway via targeting the STAT3 gene. Eur Rev Med Pharmacol Sci 23: 982-991, 2019.

60. Yue W, Zheng X, Lin Y, Yang CS, Xu Q, Carpizo D, Huang H, DiPaola RS and Tan XL: Metformin combined with aspirin significantly inhibit pancreatic cancer cell growth in vitro and in vivo by suppressing anti-apoptotic proteins Mcl-1 and Bcl-2. Oncotarget 6: 21208-21224, 2015.

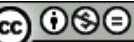

This work is licensed under a Creative Common Attribution-NonCommercial-NoDerivatives 4.0 International (CC BY-NC-ND 4.0) License. 